\title{
Fecal Lipid Content, Serum Lipid Profile, and Intra-Abdominal Fat Accumulation in Normal Rats Supplemented with Rice Bran Oil
}

\section{Evy Damayanthi ${ }^{1}$, Hana Fitria Navratilova ${ }^{1 *}$, Romadhony Ardiansyah ${ }^{1}$, Intan Nur Fitriyana $^{1}$, Retno Damayanti Soejoedono ${ }^{2}$, Maggy Thenawidjaja ${ }^{3}$}

\author{
${ }^{1}$ Department of Community Nutrition, Faculty of Human Ecology, \\ IPB University, Bogor 16680, Indonesia \\ ${ }^{2}$ Department of Animal Disease \& Veterinary Public Health, Faculty of Veterinary Medicine, \\ IPB University, Bogor 16680, Indonesia \\ ${ }^{3}$ Department of Food Science and Technology, Faculty of Agricultural Technology, \\ IPB University, Bogor 16680, Indonesia
}

\begin{abstract}
This study aimed to investigate the mechanism of rice bran oil on altering lipid absorption and blood lipid level in normal rat. Male Sprague Dawley rat age 3 months old, weighted 250-300 g were grouped into three groups: control (aquabidest $1 \mathrm{ml})$, orlistat $(2.16 \mathrm{mg} / 200 \mathrm{~g}$ body weight), and rice bran oil (1.04 mg $\gamma$-oryzanol / $200 \mathrm{~g}$ body weight). The intervention was given through oral gavage, daily for 28 days. Indicators observed were growth performance, total cholesterol and serum triglyceride levels, lipid levels in feces, and accumulation of intra-abdominal fat. The results showed that the treatment did not significantly affect body weight gain. Fecal lipid levels of orlistat, rice bran oil and control group respectively were $0.19 \mathrm{~g} ; 0.17 \mathrm{~g}$ and $0.13 \mathrm{~g}(\mathrm{p}<0.05)$, while the percentage of indigestible lipids for orlistat, control and rice bran oil group were $26 \%, 17 \%$ and $13 \%$ respectively $(\mathrm{p}<0.05)$. Total cholesterol and serum triglyceride levels in rice bran oil group were significantly lower than controls. Rice bran oil did not significantly affect the percentage of total intra-abdominal fat and the weight of the heart and kidney $(p>0.05)$. The intervention of rice bran oil was shown to reduce blood cholesterol and triglyceride levels in normal mice and did not accumulate intra-abdominal fat. The results suggest that rice bran oil might have an effect on blood lipid regulation but not by preventing lipid absorption.
\end{abstract}

Keywords: cholesterol, fecal lipids, normal rat, orlistat, rice bran oil

\section{INTRODUCTION}

Lipid accumulation especially in abdominal adipose tissue might disrupt lipid metabolism and is often associated with main risk factors of degenerative diseases such as type 2 diabetes mellitus, hypertension, cardiovascular diseases, and dyslipidemia (Golay \& Ybarra 2005; Kotchen 2010; Akil \& Ahmad 2011; Klop et al. 2013). Rice bran has been acknowledged as one of natural remedies for prevention of degenerative diseases, due to its functional components such as antioxidants, dietary fiber, vitamins, essential minerals, and enzyme inhibitors (Hamada 2000). The antioxidant capacity of rice bran is 28.74 AEAC, 15 times more than tomato juice that has 1.87 AEAC (Damayanthi et al. 2010).

Oil can be extracted from rice bran which constitutes up to $18-22 \%$ of oil. Rice bran oil has slightly sweet taste due to a high content of 4-monomethylsterols (Cicero \& Derosa 2005). It is readily sold in supermarket thus can easily be used to substitute palm oil. Rice bran oil contains $\gamma$-oryzanol, a mixture of ferulic acid esters of phytosterols and triterpene alcohols, as bioactive compound which has high antioxidant capacity (Damayanthi et al. 2004). Previous studies showed that rice bran oil significantly lowered total cholesterol and serum LDL on rats with hypercholesterolemia (Tong et al. 2014; Most et al. 2005).

It is hypothesized that the serum lipid lowering effect from rice bran oil is due to its $\gamma$-oryzanol content, not from its dietary fiber or fatty acid composition, that inhibit lipid absorption in small intestines and excrete it through feces (Ijiri et al. 2015). Study by Bhaskaragoud et al. (2016) showed that $\gamma$-oryzanol from rice bran oil affect

"Corresponding Author: tel: +628158220213, email: hana.fitria@apps.ipb.ac.id 
lipid absorption by decreasing intestinal lipase activity. Thus, the amount of lipid absorbed also reduced. However, a more detailed mechanism of action of the lipase inhibitor of rice bran oil has not been described.

In this study we examined the effect of rice bran oil on inhibition of lipid absorption compared to orlistat (lipase inhibitor drug). To evaluate lipid absorption of rats fed with standard diet with addition of rice brain oil or orlistat, we examined rat's growth performance, fecal lipid content, serum lipid profile, and the intraabdominal fat accumulation.

\section{METHODS}

\section{Design, location, and time}

This study was an experimental study using a Randomized Block Design (RBD). Animal intervention was conducted at IPB Veterinary Teaching Hospital, IPB University. Lipid serum analysis, fecal lipid analysis, and organs weighing were performed at Laboratory of Food Analysis and Chemistry of Department of Community Nutrition of IPB University. The study was conducted from April to November 2018. The experiment obtained ethical clearance from Ethics Commission of IPB Veterinary Teaching Hospital, IPB University number 093/ KEH/SKE/VIII/2018.

\section{Materials and tools}

Twenty-one male Sprague Dawley rats at 3 month of age were purchased from Tropical Biopharmaca Research Center of IPB University. Rice bran oil (Oryza Grace ${ }^{\circledR}$ ) was obtained from supermarket in Bogor. Orlistat $\left(\mathrm{Xenical}^{\mathbb{Q}}\right.$ ) was obtained from pharmacy in Bogor. Control diet was from Indonesia Formula Feed (Indonesia Formula Feed). Blood lipid profile analysis used the Cholesterol Reagent Kit (DiaSys) and Triglyceride Reagent Kit (DiaSys). Fecal lipid analysis used the Soxhlet method with hexane as solvent. Body weight and the weight of intraabdominal fat, kidney, heart, and liver were measured by digital scale.

\section{Procedure}

Animals and treatment. The rats were individually housed in wired-bottomed aluminum cage $(170 \times 170 \times 240 \mathrm{~mm})$ and provided with water and control diet ad libitum. The room temperature was maintained at $25^{\circ} \mathrm{C}$ with 12 hours dark and 12 hours light period every day. The adaptation period was 7 days, followed by random assignment of the rats into three groups on day 8: 1. control diet (energy 2,750 kcal $/ 100 \mathrm{~g}, 4 \%$ fat, $23 \%$ crude protein, $17 \%$ digestible crude protein, $5 \%$ crude fiber) and $1 \mathrm{ml}$ of aquabidest; 2 . control diet and orlistat with dose of $10.8 \mathrm{mg} / \mathrm{kg} \mathrm{BB} ; 3$. control diet and rice bran oil with dose of $57.6 \mathrm{mg}$ $\gamma$-oryzanol/day. Orlistat solution was prepared by diluting $64.8 \mathrm{mg}$ of crushed orlistat tablet into 100 $\mathrm{ml}$ of $1 \% \mathrm{Na}-\mathrm{CMC}$ to obtain final orlistat content of $0.0648 \%$. Concentration of orlistat solution given to rat was adjusted weekly according to its body weight. Final volume given to rat was not exceeding $5 \mathrm{ml}$. Treatment was given daily for 28 days. Aquabidest, orlistat, and rice bran oil were given through oral gavage daily at $9 \mathrm{am}$. Body weight was measured every week. Feed intake was measured every day. Feed efficiency were calculated as proportion of feed intake to body weight gain. All rats were euthanized under anesthesia. Blood was collected through the jugular vein. The liver, heart, adipose tissues (mesenteric, retroperitoneal, and epididymal), and kidney were collected and weighed. Fecal samples were collected during last 4 days of the experiment.

Serum Lipid Profile Analysis. The level of triglycerides and total cholesterol were measured using reagent kit (DiaSys) according to the manufacturer's procedure.

Determination of lipid content of feces. Fat content of feces were measured using Sohxlet method. Feces from the last four days were dried in the oven, then grinded and homogenized. Homogenized fecal sample for analysis were sampled ( $2 \mathrm{~g} / \mathrm{sample})$ using AOAC Official Method 925.08 sampling method. Hexane was used as solvent and heating process was running for 6 hours. Fat content was calculated as percentage of amount of lipid extracted to sample weight.

\section{Data analysis}

Data were expressed as means \pm SEM. Analysis for body weight difference pre and post intervention was performed using paired sample t-test. Feed intake, organ weight, and serum lipid profile were analyzed using ANOVA. All statistics analyses were performed with SPSS version 22.0 for Windows. 


\section{RESULTS AND DISCUSSION}

\section{Effect of rice bran oil (RBO) on rat growth performance}

The effect of RBO on body weight gain, average calorie intake, feed efficiency and lipid absorption are presented in Table 1. After 28 days, total body weight gain of RBO group was not different from the control group. Although the daily calorie intake between groups did not differ significantly, daily lipid intake of RBO group was significantly higher than other groups. This is resulted from the induction of RBO that contributed to additional lipid intake. Both RBO and Orlistat group have higher fecal lipid content.

In this study we observed that in normal physiology state, RBO will not result in significant body weight gain. This finding is in line with previous study which showed that rats intervened with High Fat Diet (HFD) did not lead to excessive body weight gain when given RBO orally along with the diet (Son et al. 2009). Moreover, study in normal rats fed either standard diet or rice bran containing diet showed a similar growth performance (Iijiri et al. 2015).

It is known that $\gamma$-oryzanol might affect lipid absorption which reflected on the number of fecal lipid content. Statistical test results showed that the Orlistat and RBO group had significantly more fecal lipid content than the control group. As it is expected from Orlistat which known to act as inhibitor of the pancreatic lipase enzyme, the increase in fecal lipid content of RBO group is thought to have different mechanism than Orlistat. The average percentage of absorbed lipid for control, orlistat, and RBO group is $83.49 \pm 0.71 \%, 73.75 \pm 1.34 \%$, and $86.96 \pm 0.27 \%$ respectively. This data show that the amount of lipid absorbed for RBO group was similar to the control group. Thus, unlike orlistat, the lipase enzyme in RBO group is not inhibited. Lipid absorption inhibition is more prominent to rats when fed with whole rice bran oil, so it might be due to the effect of insoluble fiber included in rice bran than $\gamma$-oryzanol (Iijiri et al. 2015). Possible explanation for higher fecal lipid content might result from higher lipid intake. Therefore, in this study RBO is not effective to prevent lipid absorption in the intestines.

\section{Effect of RBO on serum lipid profile}

The effect of RBO on the total cholesterol and triglyceride level are presented in Table 2. RBO has significantly lower total cholesterol and triglycerides level than the control. Moreover, the low level was comparable to Orlistat treatment. This blood lipid lowering effect might be due to $\gamma$-oryzanol content in RBO.

It is known that $\gamma$-oryzanol is able to inhibit cholesterol and triglycerides absorption in the intestines and excrete it into feces (Rong et al. 1997; Wilson et al. 2007). However, as mentioned previously, we found that RBO group showed to have higher percentage of

Table 1. Growth performance and lipid absorption

\begin{tabular}{cccc}
\hline Parameter & Control $(\mathrm{n}=5)$ & Orlistat $(\mathrm{n}=5)$ & $\mathrm{RBO}(\mathrm{n}=5)$ \\
\hline Growth Performance & & & \\
Body weight gain (g/28 days) & $25.20 \pm 8.40^{\mathrm{a}}$ & $6.40 \pm 9.54^{\mathrm{a}}$ & $20.00 \pm 8.23^{\mathrm{a}}$ \\
Calorie intake (kcal/day) & $550.00 \pm 81.10^{\mathrm{a}}$ & $521.30 \pm 51.60^{\mathrm{a}}$ & $491.20 \pm 72.40^{\mathrm{a}}$ \\
Feed efficiency & $0.04 \pm 0.01^{\mathrm{a}}$ & $0.01 \pm 0.02^{\mathrm{a}}$ & $0.04 \pm 0.02^{\mathrm{a}}$ \\
Lipid Absorption & & & \\
Lipid intake (g/day) & $0.80 \pm 0.33^{\mathrm{a}}$ & $0.76 \pm 0.36^{\mathrm{a}}$ & $1.29 \pm 0.28^{\mathrm{b}}$ \\
Fecal lipid content (g) & $0.13 \pm 0.01^{\mathrm{b}}$ & $0.19 \pm 0.01^{\mathrm{a}}$ & $0.17 \pm 0.01^{\mathrm{a}}$ \\
\hline
\end{tabular}

Data are expressed as the mean \pm SEM; Different letters ( $a$ and $b$ ) indicate significant difference at $\mathrm{p}<0.05$ in the one-way ANOVA; RBO: Rice Bran Oil 
Navratilova et al.

Table 2. Blood lipid profile

\begin{tabular}{lccc}
\hline \multicolumn{1}{c}{ Parameter } & Control $(\mathrm{n}=5)$ & Orlistat $(\mathrm{n}=5)$ & RBO $(\mathrm{n}=5)$ \\
\hline Total Cholesterol $(\mathrm{mg} / \mathrm{dl})$ & $57.99 \pm 0.99^{\mathrm{a}}$ & $48.15 \pm 0.03^{\mathrm{b}}$ & $46.89 \pm 0.20^{\mathrm{b}}$ \\
Triglyceride $(\mathrm{mg} / \mathrm{dl})$ & $65.30 \pm 0.74^{\mathrm{a}}$ & $50.96 \pm 0.26^{\mathrm{b}}$ & $53.06 \pm 0.43^{\mathrm{b}}$ \\
\hline
\end{tabular}

Data are expressed as the mean \pm SEM; Different letters ( $a$ and $b$ ) indicate significant difference at $\mathrm{p}<0.05$ in the one-way ANOVA; RBO: Rice Bran Oil

lipid absorbed compared to control and orlistat. Therefore, assumption that $\gamma$-oryzanol prevent lipid absorption is ruled out. While in this study we cannot confirmed the number of cholesterols absorbed, $\gamma$-oryzanol can also target HMG-KoA reductase which suppresses mevalonate synthesis (Chithra et al. 2015). Reduction in mevalonate will eventually lower cholesterol level in plasma. We assumed the role of $\gamma$-oryzanol is more on regulating lipid metabolism instead of inhibiting lipid absorption.

Unlike saturated fat, total fat intake has proven to have no significant association with total cholesterol and triglyceride level (Joy et al. 2007). Rice bran oil composed of mostly unsaturated fatty acids (75\%) compared to saturated fatty acids (25\%). Thus, even though supplementation of RBO increase the total fat intake, effect on blood lipid profile distortion is low. Along these lines, beneficial effect of RBO on improving plasma lipid level can also be seen in normal physiology state.

\section{Effect of RBO on tissue weight}

Rats in the RBO group tend to have lower intra-abdominal adipose tissue $(1.11 \pm 0.45 \% \mathrm{bw})$ compare to control $(1.41 \pm 0.18 \% \mathrm{bw})$ and orlistat $(1.23 \pm 0.24 \% \mathrm{bw})$ group as shown in Table 3 . However, these differences are not significant. This finding is in line with previous studies which showed that oryzanol is able to significantly decreased epididymal, mesenteric, and peritoneal fat, but not kidney and heart (Wang et al. 2015; Iijiri et al. 2015; Charkonpunya 2010; Kobayashi et al. 2019).

Mechanism on how RBO able to prevent lipid accumulation is still unknown. However, study by Yang et al. (2019) found that rice bran can alleviate adiposity by partially reducing the increase of diglycerides and triglycerides in obese rats. Furthermore, study on molecular level shows that RBO down-regulate lipogenic genes, such as Sod1 and Cat, which reduce hepatic level of triacylglycerol (Ahmed et al. 2018). This result suggests that RBO has some roles in regulating

Table 3. Effect on tissue weight

\begin{tabular}{lccc}
\hline \multicolumn{1}{c}{ Parameter } & Control $(\mathrm{n}=5)$ & Orlistat $(\mathrm{n}=5)$ & RBO $(\mathrm{n}=5)$ \\
\hline Final Body Weight (g) & $305.80 \pm 7.70^{\mathrm{b}}$ & $278.40 \pm 15.98^{\mathrm{a}}$ & $290.30 \pm 9.35^{\mathrm{a}}$ \\
Total intra-abdominal fat (\%bw) & $1.41 \pm 0.18^{\mathrm{a}}$ & $1.23 \pm 0.24^{\mathrm{a}}$ & $1.11 \pm 0.45^{\mathrm{a}}$ \\
Mesenteric fat (\%bw) & $0.34 \pm 0.08^{\mathrm{a}}$ & $0.24 \pm 0.05^{\mathrm{a}}$ & $0.28 \pm 0.14^{\mathrm{a}}$ \\
Retroperitoneal fat (\%bw) & $0.34 \pm 0.18^{\mathrm{a}}$ & $0.31 \pm 0.14^{\mathrm{a}}$ & $0.25 \pm 0.24^{\mathrm{a}}$ \\
Epididymal fat (\%bw) & $0.73 \pm 0.09^{\mathrm{a}}$ & $0.68 \pm 0.17^{\mathrm{a}}$ & $0.58 \pm 0.25^{\mathrm{a}}$ \\
Kidney (\%bw) & $0.69 \pm 0.04^{\mathrm{a}}$ & $0.64 \pm 0.04^{\mathrm{a}}$ & $0.68 \pm 0.08^{\mathrm{a}}$ \\
Heart (\%bw) & $0.32 \pm 0.02^{\mathrm{a}}$ & $0.32 \pm 0.04^{\mathrm{a}}$ & $0.30 \pm 0.02^{\mathrm{a}}$ \\
\hline
\end{tabular}

Data are expressed as the mean \pm SEM; Different letters ( $a$ and $b$ ) indicate significant difference at $p<0.05$ in the one-way ANOVA; \%bw $=\%$ body weight; RBO: Rice Bran Oil 
adiposity. Further studies are necessary to confirm this mechanism.

\section{CONCLUSION}

Beneficial effect of RBO supplementation on blood lipid level in this study does not derived from inhibition of lipid absorption. While the exact mechanism is still unknown, RBO supplementation in normal physiology did not affect both final body weight and tissue weight of intra-abdominal fat, kidney, and heart. This study was performed in rat thus careful interpretation is needed when translating this study result into human subject.

\section{ACKNOWLEDGEMENT}

This research received a grant from Ministry of Research, Technology \& Higher Education Penelitian Dasar Unggulan Perguruan Tinggi 2018.

\section{AUTHOR DISCLOSURES}

The authors have no conflict of interest.

\section{REFERENCES}

Ahmed MA, Mohammed MA, Rashed LA, Abd Elbast SA, Ahmeed EA. 2018. Rice bran oil improves insulin resistance by affecting the expression of antioxidants and lipidregulatory genes. Lipids 53(5): 505-515. https://doi.org/10.1002/lipd.12045.

Akil L, Ahmad HA. 2011. Relationship between obesity and cardiovascular disease in Four Southern States and Colorado. J Health Care Poor Underserved 22(4 Suppl): 6172. doi:10.1353/hpu.2011.0166.

Bhaskaragoud G, Rajath S, Mahendara VP, Kumar GS, Krishna AGG, Kumar GS. 2016. Hypolipidemic mechanism of oryzanol components- ferulic acid and phytosterols. Buochem Biophys Res Commun doi: 10.1016/j.bbrc.2016.05.053.

Charkonpunya C, Sireeratwong S, Komindr S, Lerdvuthisoppon N. 2010. Effect of ricebran water extract on energy metabolism in rats fed a high-fat diet [Thesis]. Khet Phra Nakhon: Thammasat University.

Chithra PK, Sindhu G, Shalini V, Parvathy R, Jayalekshmy A, Helen A. 2015. Dietary
Njavara rice bran oil reduces experimentally inducedhypercholesterolemiaby regulating genes involved in lipid metabolism. Br J Nutr 113(08):1207-1219. doi: https://doi / org/10.1017/S0007114515000513.

Cicero AFG, Derosa G. 2005. Rice bran and its main components: Potential role in themanagement of coronary risk factors. Curr Top Nutraceutical Res 3(1):29-46.

Damayanthi E, Muchtadi D, Zakaria FR, Syarief H, Wijaya CH , Damardjati DS. 2004. Aktivitas antioksidan minyak bekatul awet dan fraksinya secara in vitro. J Teknologi dan Industri Pangan. 15(1):11-19.

Damayanthi E, Kustiyah L, Khalid M, Farizal H. 2010. Aktivitas antioksidan bekatul lebih tinggi daripada jus tomat dan penurunan aktivitas antioksidan serum setelah intervensi minuman kaya antioksidan. J Gizi Pangan 5(3): 205-210. doi: https:// doi.org/10.25182/jgp.2010.5.3.205-210.

Golay A, Ybarra J. 2005. Link between obesity and type 2 diabetes. Best Pract Res Clin Endocrinol Metab 19(4):649-663. https:// doi.org/10.1016/j.beem.2005.07.010.

Hamada JS. 2000. Characterization and functional properties of rice bran proteins modified by commercial exoproteases and endoproteases. J Food Sci 65(2): 305-310. https://doi.org/10.1111/j.1365-2621.2000. tb15998.x.

Ijiri J, Nojima T, Kawaguchi M, Yamauchi Y, Fujita Y, Ijiri S, Ohtsuka A. 2015. Effect of feeding outer bran fraction of rice on lipid accumulation and fecal excretion in rats. Biosci Biotechnol Biochem 79(8):13371341. https://doi.org/10.1080/09168451.2 015.1032883.

Joy T, Keogh HM, Hadigan C, Lee H, Dolan SE, Fitch K, Liebau J, Lo J, Johnsen S, Hubbard J, Anderson EJ, Grinspoon S. 2007. Dietary fat intake and relationship to serum lipid levels among HIV-innfected subjects with metabolic abnormalities in the era of HAART AIDS 21(12): 1591-1600. doi: 10.1097/QAD.0b013e32823644ff.

Kobayashi E, Ito J, Shimizu N, Kokumai T, Kato S, Sawada K, Hashimoto H, Eitsuka T, Miyazawa T, Nakagawa K. 2019. Evaluation of $\gamma$-oryzanol accumulation and lipid metabolism in the body of mice following long-term administration of 
$\gamma$-oryzanol. Nutrients 11(1): 104. https:// doi.org/10.3390/nu11010104.

Klop B, Elte JWF, Cabezas MC. 2013. Dyslipidemia in obesity : Mechanism and potential targets. Nutrients 5(4):12181240. https://doi.org/10.3390/nu5041218.

Kotchen TA. 2010. Obesity-related hypertension : Epidemiology, pathophysiology, and clinical management. Am J Hypertens 23(11):1170-1178.https://doi. org/10.1038/ajh.2010.172.

Most MM, Tulley R, Morales S, Lefevre M. 2005. Rice bran, not fibre, lowers cholesterol in humans. Am J Clin Nutr 81: 64-68. https:// doi.org/10.1093/ajen/81.1.64.

Rong N, Ausman LM, Nicolosi RJ. 1997. Oryzanol decreases cholesterol absorption and aortic fatty streaks in hamsters. Lipids. 32(3):303-309. https://doi.org/10.1007/ s11745-997-0037-9.

Son MJ, Rico CW, Nam SH, Kang MY. 2009. Influence of oryzanol and ferulic acid on the lipid metabolisme and antioxidative status in high fat-fed mice. J Clin Biochem Nutr 46(2):150-156. https://doi.org/10.3164/ jcbn.09-98.

Tong LT, Zhong K, Liu Y, Guo L, Cao L, Zhou S. 2014. Oat oil lowers the plasma and liver cholesterol concentrations by promoting the excretion of faecal lipids in hypercholesterolemic rats. Food Chem 142:129-134. https://doi.org/10.1016/j. foodchem.2013.07.028.

Wang O, Liu J, Cheng Q, Guo X, Wang Y, Zhao L, Zhou F, Ji B. 2015. Effects of ferulic acid and $\gamma$-oryzanol on high-fat and highfructose diet-induced metabolic syndrome in rats. Plos One 10(2): e0118135. doi :10.1371/journal.pone.0118135.

Wilson TA, Nicolosi RJ, Woolfrey B, Kritchevsky D. 2007. Rice bran oil and oryzanol reduce plasma lipid and lipoprotein cholesterol ester accumulation to a greater extent than ferulic acid in hypercholesterolemic hamster. J Nutr Biochem 18(2): 105-112. $\quad$ https://doi.org/10.1016/j. jnutbio.2006.03.006.

Yang SC, Huang WC, Ng XE, Lee MC, Hsu YJ, Huang CC, Wu HH, Yeh CL, Shirakawa H, Budijanto S, et al. 2019. Rice bran reduces weight gain and modulates lipid metabolism in rats with high-energy-dietinduced obesity. Nutrients 11(9): 2033. doi:10.3390/nu11092033. 